\title{
Freeze-lysable inorganic nutrients in intertidal sediments: dependence on microphytobenthos abundance
}

\author{
Emilio García-Robledo ${ }^{1, *}$, Alfonso Corzo ${ }^{1}$, Sokratis Papaspyrou ${ }^{1,2}$, \\ Juan L. Jiménez-Arias ${ }^{1}$, Desirée Villahermosa ${ }^{1}$ \\ ${ }^{1}$ Departamento Biología, Facultad de Ciencias del Mar y Ambientales, Universidad de Cádiz, Pol. Río San Pedro s/n, \\ 11510- Puerto Real, Cádiz, Spain \\ ${ }^{2}$ Instituto de Ciencias Marinas de Andalucía (CSIC), Pol. Rio San Pedro s/n, 11510 Puerto Real, Cádiz, Spain
}

\begin{abstract}
Freezing is a common treatment for the preservation of sediment samples. To test the role of microphytobenthos (MPB) abundance in the release of intracellular nutrients to the pore water due to cell breakage after freezing, referred to as freeze-lysable inorganic nutrients (FL-IN), parallel extractions were carried out from intertidal sediment cores collected in winter and summer from Cádiz Bay. After the determination of net production and dark respiration rates with $\mathrm{O}_{2}$ microsensors, sediment cores were subcored and sliced into several layers. The samples were divided into 2 fractions; the first was centrifuged to extract pore water (fresh) and the other was frozen at $-80^{\circ} \mathrm{C}$, thawed and centrifuged to extract pore water after freezing. $\mathrm{NO}_{2}{ }^{-}, \mathrm{NO}_{3}{ }^{-}, \mathrm{NH}_{4}{ }^{+}$and $\mathrm{PO}_{4}{ }^{3-}$ were measured in the pore water extracted by both procedures. Chlorophylls $a$ and $c$ were extracted from the same sediment fractions. Freezing produced a significant increase in the pore water concentrations of all inorganic nutrients. Therefore, if the variable of interest is the inorganic nutrient concentration, pore water should be extracted from fresh samples. In addition, FL-IN correlated significantly with chlorophylls $a$ and $c(\mathrm{p}<0.01), \mathrm{r}^{2}$ ranged from 0.54 for $\mathrm{NO}_{3}{ }^{-}$to 0.94 for $\mathrm{NH}_{4}{ }^{+}$, indicating that most FL-IN were released from MPB biomass. The relationships between chlorophyll $a$ and FL-IN in winter and summer were significantly different, suggesting that nutrient accumulation by MPB changes seasonally and might affect nutrient cycling in intertidal sediments.
\end{abstract}

KEY WORDS: Microphytobenthos $\cdot$ Microbenthos $\cdot$ Freeze-lysable inorganic nutrients $\cdot$ Pore water nutrients $\cdot$ Intertidal sediments $\cdot$ Benthic microalgae $\cdot$ Sediment preservation

\section{INTRODUCTION}

The analysis of inorganic nutrients in the sediment pore water and the overlying water column allows biogeochemists to calculate diffusive fluxes at the sediment-water interface (Boudreau 1997). In addition, numerical modelling of inorganic nutrient profiles within the sediment has been used to calculate the rates and location of several biogeochemical activities within the sediment (Berg et al. 1998). Therefore, any alteration of the in situ pore water concentration during collection, storage or extraction of pore water from the cores would introduce serious errors in the calculation and interpretation of biogeochemical processes (Sayama 2001).

Freezing is often used to preserve sediment samples in biogeochemical studies when a large number of them must be collected. It is assumed, although generally not tested, that this practise will prevent sediment mixing during transportation and 'stop' any further biogeochemical process occurring within the sediment. Once in the laboratory, sediment cores are thawed and processed for the extraction of pore water nutrients. However, this practice may produce erro- 
neous results. It is well established that freezing causes cell breakage and release of cytoplasmic compounds into the external medium. Freezing-thawing cycles have been used to extract intracellular pools of inorganic nitrogen (Thoresen et al. 1982) and nucleic acids from marine phytoplankton (More et al. 1994). Freezing of marine sediments has been shown to increase the concentration of extracted pore water inorganic nutrients (Lomstein et al. 1990, Aller 1994, Sayama 2001, Ferguson et al. 2004) and dissolved organic carbon (Otero et al. 2007). The characteristic exponential decrease with depth in the concentration of pore water freeze-lysable (FL) nitrate and ammonium (defined here as the difference between the concentrations of inorganic nutrients in thawed and fresh aliquots of the same sample) and their increase after the sedimentation of a phytoplankton bloom in subtidal sediments lead Lomstein et al. (1990) to suggest that $\mathrm{FL}-\mathrm{NO}_{3}{ }^{-}$and FL- $\mathrm{NH}_{4}{ }^{+}$might represent the intracellular pool of the sedimented phytoplankton cells. However, other components of the benthic community may also release intracellular nutrients after freezing. $\mathrm{FL}-\mathrm{NO}_{3}{ }^{-}$was at least 10 times higher than the $\mathrm{NO}_{3}{ }^{-}$pore water concentration in the hypertrophic subtidal sediments of Tokyo Bay due to the abundance of nitrate-accumulating sulphur bacteria (Sayama 2001). FL- $\mathrm{NH}_{4}{ }^{+}$and $\mathrm{FL}-\mathrm{PO}_{4}{ }^{3-}$ have also been interpreted as originating mainly from intracellular pools associated with microbial and meiofaunal biomass (Aller 1994, Ferguson et al. 2004). High concentrations of FL inorganic nutrients (FL-IN) were found in intertidal sediments below macroalgal mats, released most likely from macroalgal detritus (Corzo et al. 2009). However, so far, no specific studies have been carried out to quantify the contribution of the different components of the complex biological community inhabiting the marine sediment to the FL-IN pool.

In intertidal areas, benthic microalgae (microphytobenthos, MPB) inhabit the sediment surface. The MPB community is usually dominated by benthic diatoms and cyanobacteria. MPB cells could release intracellular nutrients when sediment samples are frozen. The aim of the present study was to test the hypothesis that FL-IN represents the intracellular nutrient pool of MPB and to assess the contribution of MPB to the release of FL-IN in sediment samples. To achieve this, we compared the concentrations of inorganic nutrients $\left(\mathrm{NO}_{3}{ }^{-}\right.$, $\mathrm{NO}_{2}{ }^{-}, \mathrm{NH}_{4}{ }^{+}$and $\mathrm{PO}_{4}{ }^{3-}$ ) in parallel fresh and freezethawed samples from different sediment depths and related these with the concentration of chlorophyll $a$ and $C_{\text {, }}$ used as an indicator of microalgal abundance. The experiment was carried out in winter and summer to test if the seasonal changes in microphytobenthos abundance and activity could affect the FL-IN content of the sediment and its relationship with chlorophyll and pore water nutrients. The experimental data were analysed at annual level by pooling the results obtained in the winter and summer experiments to cover as much variability as possible and by seasons to reveal possible changes in the relationships among FLIN, chlorophyll and pore water nutrients.

\section{MATERIALS AND METHODS}

Sampling site and collection of samples. Sediment samples were collected in January and July 2008 from an unvegetated intertidal site in Trocadero Island (Cadiz Bay, Spain). Sediment was silty mud and no macroalgae or seagrasses detritus were observed in the samples. Two sediment cores (internal diameter [i.d.] $5.4 \mathrm{~cm}$ ) were collected from each of 3 randomly selected $1 \times 1 \mathrm{~m}$ sediment areas with a typical separation between areas of 10 to $15 \mathrm{~m}$.

Sample processing. After collection, sediment cores were carried to the laboratory and maintained in an aquarium, at a photon flux density (PFD) of $800 \mu \mathrm{mol}$ $\mathrm{m}^{-2} \mathrm{~s}^{-1}$ provided by halogen lamps, under a $12 \mathrm{~h}$ light: $12 \mathrm{~h}$ dark photoperiod cycle for 4 to $5 \mathrm{~d}$ until further analysis. The aquarium was under a semidiurnal tidal cycle, simulated with the help of 2 pumps connected to time controllers. $\mathrm{O}_{2}$ profiles ( $\mathrm{n}=3$ to 4 ) were measured in the light $\left(800 \mu \mathrm{mol}\right.$ photons $\left.\mathrm{m}^{-2} \mathrm{~s}^{-1}\right)$ and in the dark at the sediment-water interface in each of the 6 sediment cores using $\mathrm{O}_{2}$ microelectrodes (Unisense A/S, Denmark). Net primary production $\left(P_{\mathrm{n}}\right)$ and dark respiration $\left(R_{\mathrm{d}}\right)$ rates were calculated from the $\mathrm{O}_{2}$ gradient at the diffusive boundary layer of the light and dark profiles respectively (Kühl et al. 1996, García-Robledo et al. 2008, Corzo et al. 2009).

After the determination of the $\mathrm{O}_{2}$ profiles, 4 smaller cores (i.d. $1.6 \mathrm{~cm}$ ) were subcored from each of the 6 cores in order to facilitate subsequent slicing at the $\mathrm{mm}$ scale. Every subcore was sliced at the following depth intervals: $0-1,1-2,2-3,3-5$ and $5-10 \mathrm{~mm}$. Slices from the same depth from each area were pooled and homogenised to obtain a sufficiently large amount of sample for subsequent analyses. These pooled sediment samples were then split into 2: one subsample was processed immediately (fresh subsample) and the other was frozen at $-80^{\circ} \mathrm{C}$ for a minimum of $24 \mathrm{~h}$ and thawed prior to further treatment (thawed subsample). Both fresh and thawed sediment samples were centrifuged at $8600 \mathrm{~g}$ for $30 \mathrm{~min}$ at $4^{\circ} \mathrm{C}$ to extract pore water. Total water content of sediment ranged from 55.1 to $60.4 \%$. Nutrient concentrations in the extracted pore water $\left(\mathrm{NH}_{4}{ }^{+}, \mathrm{NO}_{2}{ }^{-}, \mathrm{NO}_{3}{ }^{-}\right.$and $\left.\mathrm{PO}_{4}{ }^{3-}\right)$ were measured on a Skalar autoanalyzer following standard protocols (Grasshoff et al. 1983). Immediately after pore water extraction, pigment extraction from the pellets 
was carried out. Chlorophyll a (chl a) and chlorophyll $\mathrm{c}(\mathrm{chl} C)$ were extracted in $100 \%$ methanol overnight at $4{ }^{\circ} \mathrm{C}$ in darkness (Thompson et al. 1999). Extracts were centrifuged at $2200 \mathrm{~g}$ for $10 \mathrm{~min}$ and measured using a spectrophotometer (Unicam UV/Vis UV2 ${ }^{\circledR}$ ). Chl $a$ and $c$ were estimated as described by Ritchie (2008).

Statistical analysis. Differences between treatments or depths for the measured variables were tested by 1-way and 2-way analysis of variance (ANOVA) followed by Tukey's HSD test for multiple pairwise comparisons. Linear regressions and correlations between variables were also performed using the software Statgraphics Plus 5.1.

\section{RESULTS}

\section{Effect of freezing on chlorophyll and inorganic nutrient extractions}

Mean chlorophyll content (winter and summer data pooled) showed similar vertical distributions (Fig. 1) with highest values at the sediment surface (mean \pm SE: $36.7 \pm$ $5.1 \mu \mathrm{g} \mathrm{chl} a \mathrm{~g} \mathrm{DW}^{-1}$ and $6.0 \pm 1.5 \mu \mathrm{g} \mathrm{chl} \mathrm{cg}$ $\mathrm{DW}^{-1}$ ) decreasing rapidly with depth (1-way ANOVA, $\mathrm{p}<0.01$ ). Both pigments showed similar vertical distribution with depth and their concentrations were highly correlated $\left(r^{2}=0.99, p<0.01\right.$, Table 1, Fig. 1). Freezing increased the extraction yield of both chl $a$ and $c$ significantly $(\sim 1.2$-fold, Fig. 1 , Table 1), however the effect of freezing on the extraction yield decreased with depth (2-way ANOVA, $\mathrm{p}<0.05$ ).

Mean pore water $\mathrm{NO}_{2}^{-}$concentration (winter and summer data pooled) measured in fresh samples decreased significantly with depth within the sediment from $0.7 \pm$ $0.3 \mu \mathrm{mol} \mathrm{l}^{-1}$ at the sediment surface to $0.2 \pm 0.1 \mu \mathrm{mol} \mathrm{l}^{-1}$ at $7.5 \mathrm{~mm}$ depth (1-way ANOVA, $\mathrm{p}<0.05)$. $\mathrm{NO}_{3}{ }^{-}$and $\mathrm{PO}_{4}{ }^{3-}$ also decreased with depth from $1.9 \pm 1.4$ and $0.9 \pm 0.4 \mu \mathrm{mol} \mathrm{l}^{-1}$, to $0.3 \pm 0.2$ and $0.2 \pm 0.1 \mu \mathrm{mol} \mathrm{l}^{-1}$, respectively, but changes were not significant due to a large variability in the upper sediment layer. $\mathrm{NH}_{4}{ }^{+}$ remained constant with depth at about $22.1 \pm 1.8 \mu \mathrm{mol}$ $1^{-1}$ (Fig. 1).

The freeze-thaw procedure prior to the extraction of sediment pore water significantly increased the pore water concentrations of analysed nutrients (2-way ANOVA, $\mathrm{p}<0.01$ ). Inorganic nutrients decreased with
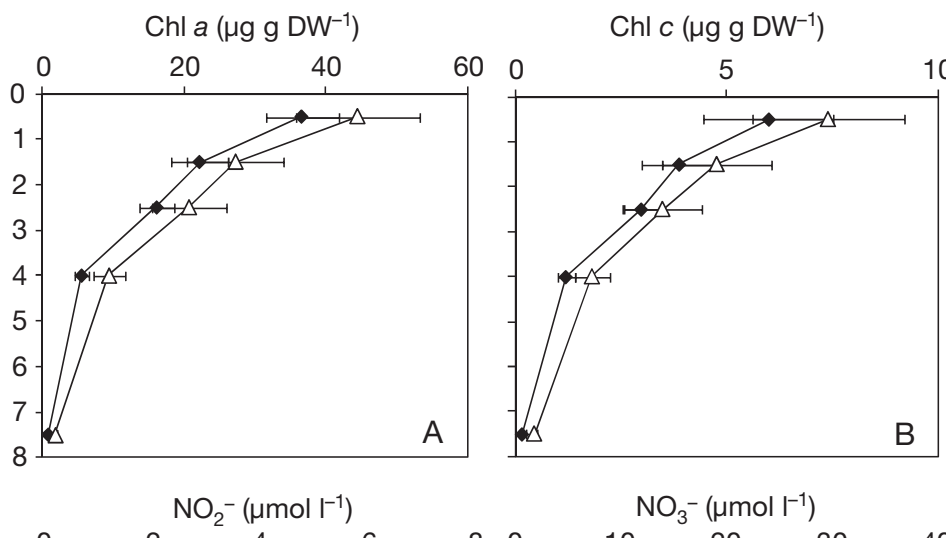

10
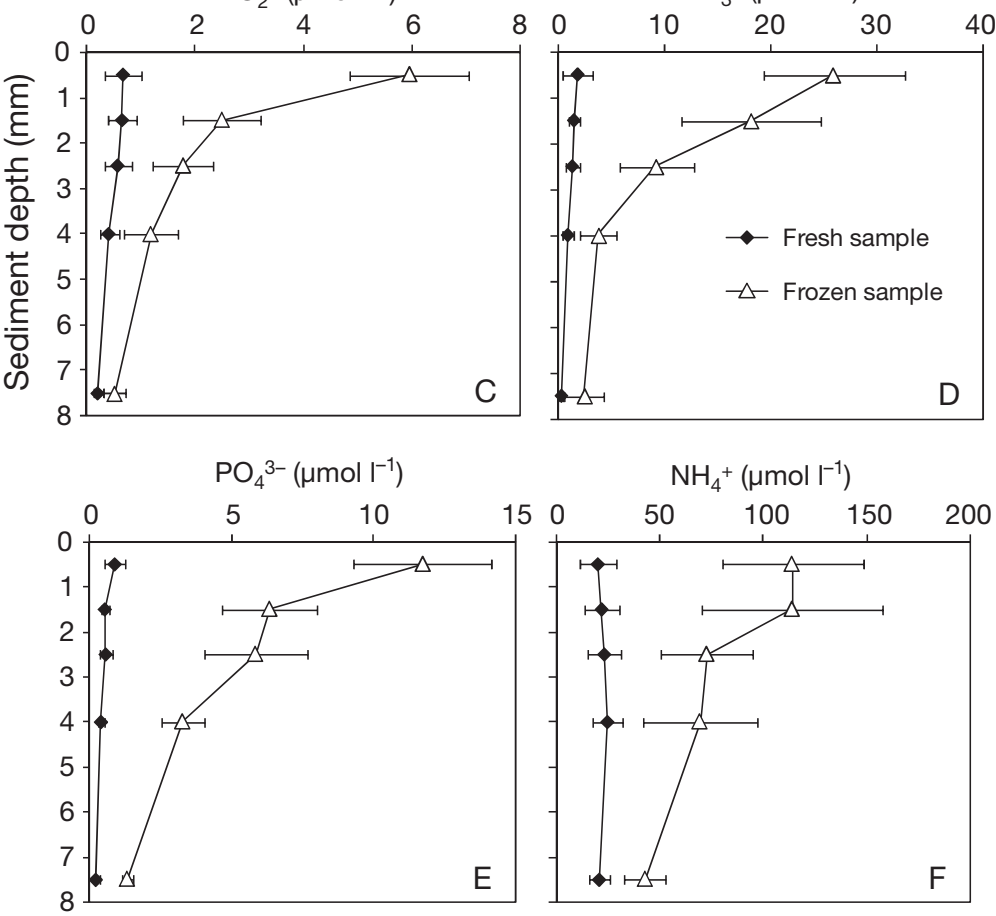

Fig. 1. Vertical profiles of (A) chlorophyll $a_{1}$ (B) chlorophyll $c$ and pore water (C) nitrite, (D) nitrate, (E) phosphate and (F) ammonium concentrations in hediment measured in parallel subsamples, 1 fresh untreated and 1 subjected to a single freeze-thaw cycle. Values are mean $\pm \operatorname{SE}(n=6)$

depth exponentially, from $5.9 \pm 1.1,26.0 \pm 6.6,11.7 \pm$ 2.4 and $113.9 \pm 33.9 \mu \mathrm{mol} \mathrm{l}{ }^{-1}$, for $\mathrm{NO}_{2}{ }^{-}, \mathrm{NO}_{3}{ }^{-}, \mathrm{PO}_{4}{ }^{3-}$ and $\mathrm{NH}_{4}{ }^{+}$, respectively, at the sediment surface to 8 to $37 \%$ of surface values at the deepest analysed sediment layer (Fig. 1).

FL-IN concentration showed similar profiles, with the highest concentrations at sediment surface and a progressive decrease with depth (Fig. 2). The highest release of nutrients after the freeze-thaw treatment was observed for $\mathrm{FL}-\mathrm{NH}_{4}{ }^{+}$ranging from $99.7 \pm$ $26.9 \mu \mathrm{mol} \mathrm{l} \mathrm{l}^{-1}$ at the sediment surface to $22.1 \pm 5.6 \mu \mathrm{mol}$ $\mathrm{l}^{-1}$ at the deepest layer. The lowest release of nutrient was observed for FL- $\mathrm{NO}_{2}^{-}$, ranging from $5.3 \pm 1.1$ at 
the surface to $0.3 \pm 0.1 \mu \mathrm{mol} \mathrm{l^{-1 }}$ at the deepest layer. FL- $\mathrm{NO}_{3}{ }^{-}$and $\mathrm{FL}-\mathrm{PO}_{4}{ }^{3-}$ ranged from $24.1 \pm 5.6$ and $10.9 \pm 2.4 \mathrm{mmol} \mathrm{l}^{-1}$ at the surface to $2.2 \pm 1.7$ and $1.1 \pm$ $0.3 \mu \mathrm{mol} \mathrm{l}^{-1}$ at the deepest layer, respectively.

Table 1. Linear regressions between concentrations of chlorophyll $a$ and $c$ in frozen and fresh samples, and between freezelysable (FL) content of nitrate, nitrite, ammonium and phosphate concentrations and chl a content in the sediment after a single freeze-thaw cycle. All regressions were statistically significant $(\mathrm{n}=30, \mathrm{p}<0.01)$. In all cases, the independent terms were set to be equal to 0 because in a previous regression analysis they were not significantly different from 0

\begin{tabular}{|lc|}
\hline Regression equations & $\mathrm{r}^{2}$ \\
\hline $\mathrm{Chl} a^{\text {frozen }}=1.24 \mathrm{chl} a^{\text {fresh }}$ & 0.91 \\
$\mathrm{Chl} c^{\text {frozen }}=1.18 \mathrm{chl} c^{\text {fresh }}$ & 0.89 \\
$\mathrm{Chl} a^{\text {frozen }}=5.69 \mathrm{chl} c^{\text {frozen }}$ & 0.99 \\
$\mathrm{Chl} a^{\text {fresh }}=5.28 \mathrm{chl} c^{\text {fresh }}$ & 0.93 \\
$\mathrm{FL}-\mathrm{NO}_{2}{ }^{-}=0.09 \mathrm{chl} a^{\text {frozen }}$ & 0.72 \\
$\mathrm{FL}-\mathrm{NO}_{3}{ }^{-}=0.43 \mathrm{chl} a^{\text {frozen }}$ & 0.54 \\
$\mathrm{FL}-\mathrm{PO}_{4}{ }^{3-}=0.24 \mathrm{chl} a^{\text {frozen }}$ & 0.88 \\
$\mathrm{FL}-\mathrm{NH}_{4}{ }^{+}=2.42 \mathrm{chl} a^{\text {frozen }}$ & 0.94 \\
\hline
\end{tabular}

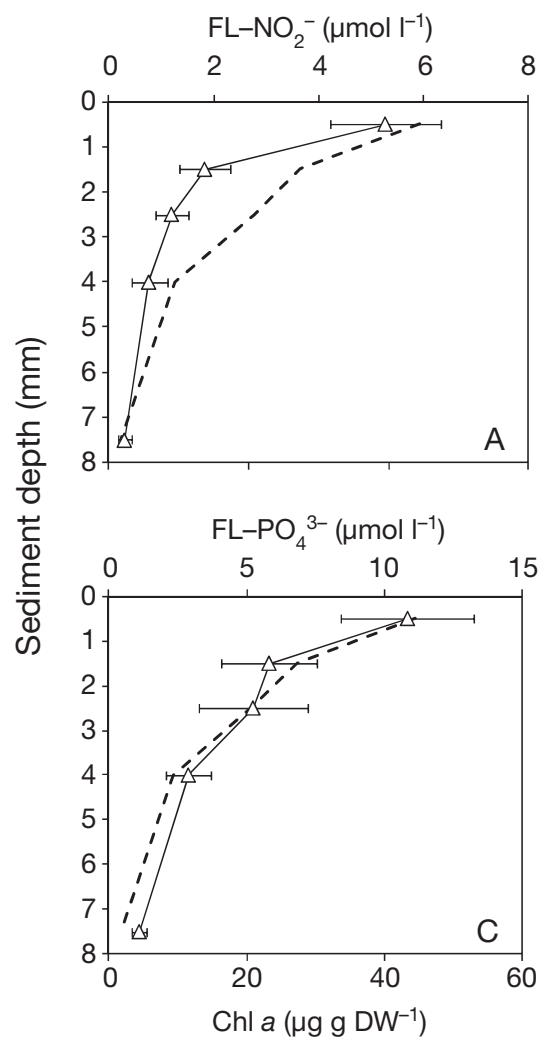

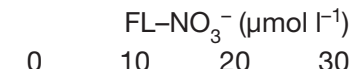

15

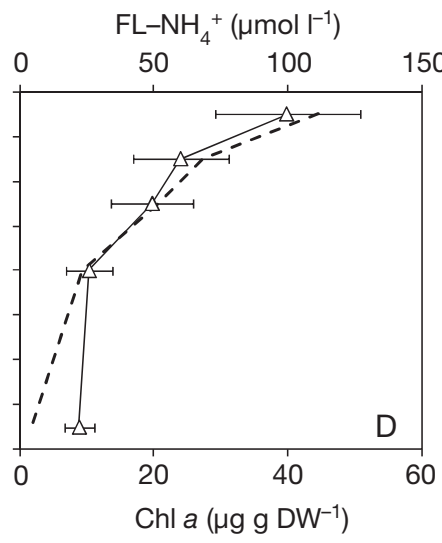

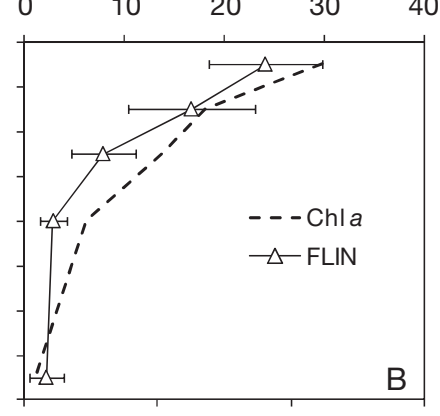

Fig. 2. Vertical profiles of freeze-lysable (FL) (A) nitrite, (B) nitrate, (C) phosphate and (D) ammonium. Freeze-lysable inorganic nutrients (FL-IN) are defined as the difference in the pore water nutrient concentration between a sediment subsample subjected to a single freeze-thaw cycle and a fresh untreated sample. Values are mean $\pm \mathrm{SE}(\mathrm{n}=6)$. Chl a profile (dashed line) is given for comparison purposes
The general pattern of the vertical profiles of all the FL-IN was similar to that of chl a (Fig. 2). FL-IN concentrations were highly correlated with those of chl a ( $p<0.01)$, although there were clear differences among the nutrients (Table 1). $\mathrm{FL}^{-} \mathrm{NH}_{4}{ }^{+}$showed the highest correlation $\left(\mathrm{r}^{2}=0.94\right)$ and $\mathrm{FL}-\mathrm{NO}_{3}{ }^{-}$the lowest $\left(\mathrm{r}^{2}=0.54\right)$. In contrast, the correlations between the pore water inorganic nutrients and chlorophyll concentrations of fresh subsamples were not significant for $\mathrm{NO}_{3}{ }^{-}, \mathrm{NH}_{4}{ }^{+}$and $\mathrm{PO}_{4}{ }^{3-}(\mathrm{p}>0.05)$, or significant but much weaker in the case of $\mathrm{NO}_{2}^{-}\left(\mathrm{r}^{2}=0.41\right.$, $\left.\mathrm{p}<0.01\right)$. Inorganic nutrient concentrations in pore water and FL-IN were significantly different (2-way ANOVA, p < $0.01)$, but were weakly correlated except for $\mathrm{PO}_{4}{ }^{3-}\left(\mathrm{r}^{2} \leq\right.$ 0.3 in all cases, $\mathrm{p}<0.01$ ).

\section{Winter and summer differences}

Chl a content in the upper layer of the sediment was higher in winter than in summer (ANOVA, p < 0.05), but the difference between seasons decreased with depth (Fig. 3A). Similar differences were found in the chl $C$ content between seasons (Fig. 3B). Oxygen supersaturation of the subsurface pore water in the light compared with the dark (Fig. 3C,D) indicates the presence of a photosynthetically active microphytobenthic community in both seasons. However, net primary production $\left(P_{\mathrm{n}}\right)$ and dark respiration $\left(R_{\mathrm{d}}\right)$ were lower in winter (Table 2).

FL-IN content of the sediment in winter and summer showed the same exponential decrease with depth previously observed for the complete data set (Fig. 4). The concentrations of FL- $\mathrm{NH}_{4}{ }^{+}, \mathrm{FL}_{-} \mathrm{NO}_{2}{ }^{-}$ and $\mathrm{FL}-\mathrm{PO}_{4}{ }^{3-}$ were higher in winter (2way ANOVA, p < 0.05). The difference between the winter and summer samples tended to decrease with depth. However, FL- $\mathrm{NO}_{3}{ }^{-}$did not show significant differences between winter and summer (Fig. 4).

The relationships between FL-IN and chl a concentration were always significant $(\mathrm{p}<0.01)$ when the winter and summer samples were analysed separately, although they varied slightly with season. The highest correlations were observed for $\mathrm{FL}_{-} \mathrm{NH}_{4}{ }^{+}$in winter and summer and for $\mathrm{FL}-\mathrm{PO}_{4}{ }^{3-}$ in winter (Table 3). Lowest correlations were observed for $\mathrm{FL}_{-} \mathrm{NO}_{3}{ }^{-}$in winter and for FL- $\mathrm{PO}_{4}{ }^{3-}$ in summer. 
Table 2. Characteristics of the microphytobenthic community in January and July. Chlorophyll values are integrated for the upper $5 \mathrm{~mm}$ of the sediment and expressed as $\mathrm{mg} \mathrm{m}^{-2}(\mathrm{n}=3)$; net production in light $\left(P_{\mathrm{n}}\right)$ and respiration in dark $\left(R_{\mathrm{d}}\right)$ as $\mathrm{mmol} \mathrm{O}_{2} \mathrm{~m}^{-2} \mathrm{~h}^{-1}(\mathrm{n}=20)$. Values are means $\pm \mathrm{SE}$

\begin{tabular}{|c|c|c|c|c|}
\hline & Chl a & Chl $C$ & $P_{\mathrm{n}}$ & $R_{\mathrm{d}}$ \\
\hline Jan & $307.2 \pm 62.9$ & $55.7 \pm 3.9$ & $1.0 \pm 0.3$ & $-0.8 \pm 0.1$ \\
\hline Jul & $128.3 \pm 21.4$ & $16.8 \pm 4.7$ & $3.9 \pm 0.4$ & $-1.2 \pm 0.1$ \\
\hline
\end{tabular}

The content of FL-IN per unit of chl $a\left(\mathrm{FL}-\mathrm{NO}_{3}{ }^{-} / \mathrm{chl} a_{\text {, }}\right.$ FL- $\mathrm{NO}_{2}{ }^{-} / \mathrm{chl} a, \mathrm{FL}^{-} \mathrm{NH}_{4}{ }^{+} / \mathrm{chl} a$ and $\mathrm{FL}-\mathrm{PO}_{4}{ }^{3-} / \mathrm{chl} a$ ) showed clear differences with depth in the sediment, and between seasons for some nutrients (Fig. 5). Two layers were evident, the upper one up to a depth of 3 to $5 \mathrm{~mm}$, characterised by relatively low concentrations of FL-IN per unit of chl $a$ and showing a wide variability of patterns in response to both depth and season among the different inorganic nutrients. The second layer, below a depth of 3 to $5 \mathrm{~mm}$, was characterised by a general increase in all FL-IN/chl a ratios except FL$\mathrm{NO}_{3}{ }^{-} / \mathrm{chl} a$ in July (Fig. 5B).

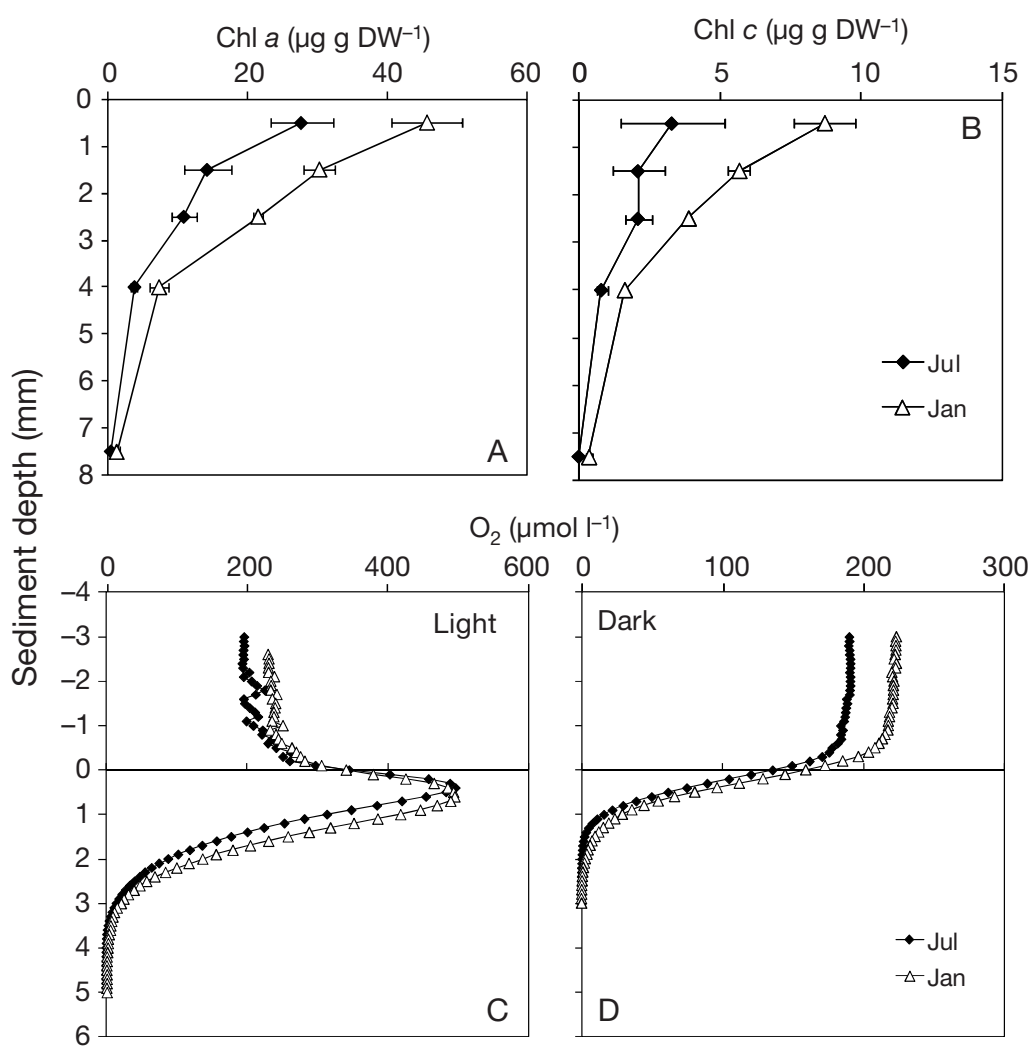

Fig. 3. Vertical distribution of (A) chl $a$ and (B) $c h l c$ in the sediment surface after freezing and thawing in January and July. Mean oxygen profiles in the sediment-water interface (C) in the light (PFD $=800 \mu \mathrm{mol} \mathrm{m}^{-2} \mathrm{~s}^{-1}$ ) and (D) in the dark in January and July. Values are mean \pm SE $(n=3)$
Table 3. Linear regressions between $\mathrm{FL}-\mathrm{NH}_{4}{ }^{+}, \mathrm{FL}-\mathrm{NO}_{2}{ }^{-}, \mathrm{FL}-$ $\mathrm{NO}_{3}{ }^{-}$and $\mathrm{FL}-\mathrm{PO}_{4}{ }^{3-}$ concentrations and chl $a$ content (as independent variable) for January and July samples. The intercept was set to 0 in all cases as it was found to be not significantly different from 0 in a previous linear regression analysis. All regressions were significant $(n=15, p<0.01)$

\begin{tabular}{|lllll|} 
& \multicolumn{2}{c}{ January } & \multicolumn{2}{c|}{ July } \\
& $\mathrm{r}^{2}$ & Slope & $\mathrm{r}^{2}$ & Slope \\
\hline FL-NH $_{4}{ }^{-}$ & 0.95 & 2.48 & 0.90 & 2.17 \\
FL-NO $_{2}{ }^{-}$ & 0.74 & 0.076 & 0.82 & 0.138 \\
FL-NO $_{3}{ }^{-}$ & 0.55 & 0.357 & 0.73 & 0.814 \\
FL-PO $_{4}{ }^{3-}$ & 0.94 & 0.248 & 0.59 & 0.181 \\
\hline
\end{tabular}

The nutrient concentration in the pore water of fresh samples differed considerably between winter and summer (Fig. 6). The changes involved not only the quantity of the different nutrients, but also the shape of their profiles with depth. $\mathrm{NO}_{3}{ }^{-}, \mathrm{NO}_{2}{ }^{-}$and $\mathrm{NH}_{4}{ }^{+}$concentrations were higher in winter, whereas $\mathrm{PO}_{4}{ }^{3-}$ concentration was higher in summer except in the upper $\mathrm{mm}$ of the sediment (2-way ANOVA, $\mathrm{p}<0.01)$. No significant statistical relationship was found between pore water nutrients and chl a concentrations in either winter or summer, except for $\mathrm{NO}_{2}^{-}$in winter $\left(\mathrm{r}^{2}=0.40, \mathrm{p}<0.01\right)$ and $\mathrm{NH}_{4}{ }^{+}$in summer $\left(\mathrm{r}^{2}=0.43, \mathrm{p}<0.01\right)$. Pore water and FL-IN nutrients in each season were not statistically correlated, except $\mathrm{NO}_{3}{ }^{-}$in winter $\left(\mathrm{r}^{2}=0.48, \mathrm{p}<0.01\right)$ and summer $\left(\mathrm{r}^{2}=0.65, \mathrm{p}<0.01\right)$.

\section{DISCUSSION}

\section{Effect of freezing and thawing on chlorophyll and nutrient extractions}

Freezing and thawing of sediment samples increased the extraction yield of all measured variables, both pigments and nutrients (Fig. 1, Table 1). Freeze-thaw cycles have been used to improve the extraction efficiency from sediment samples of nucleic acids (More et al. 1994), dissolved organic matter (Otero et al. 2007), as well as pigments (Wasmund et al. 2006). The cell lysis induced by freezing also results in the release of dissolved intracellular inorganic nutrients to the sediment pore water (Lomstein et al. 1990, Sayama 2001). This was evident in our study, as nutrient pore water concentrations increased up to 120 -fold after a single freeze-thaw cycle (Fig. 1). There- 


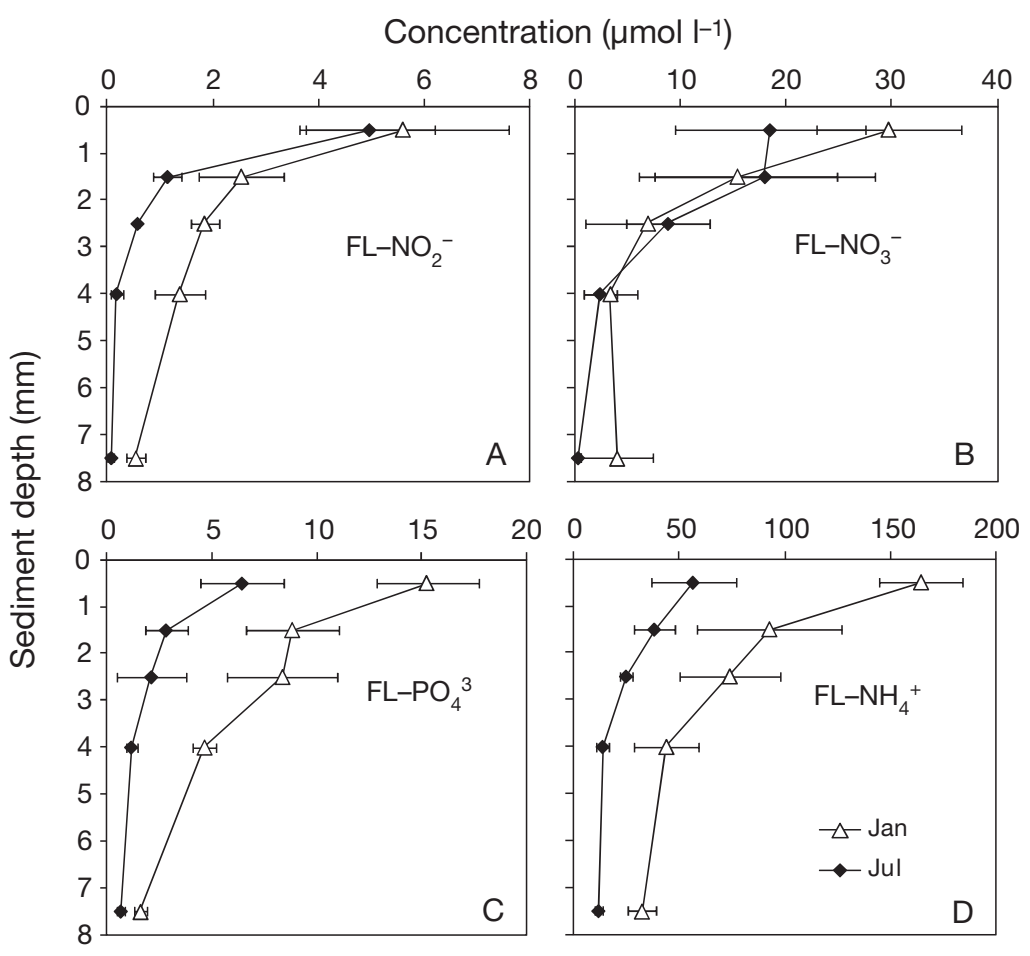

Fig. 4. Vertical profiles of FL-IN: (A) nitrite, (B) nitrate, (C) phosphate and (D) ammonium in January and July. Values are mean \pm SE $(n=3)$ inorganic nutrients in benthic microalgae as far as we know. Nonetheless, the range of $\mathrm{FL}-\mathrm{NO}_{3}{ }^{-} / \mathrm{chl}$ a reported here (Fig. 5) is consistent with published data for phytoplanktonic communities. Bode et al. (1997) found that the amount of intracellular $\mathrm{NO}_{3}{ }^{-}$normalised to chl a was $4.3 \pm$ $2.5 \mathrm{nmol} \mathrm{NO}_{3}^{-} \mu^{-1} \mathrm{chl}$ a in a coastal upwelling system off northern Spain. In more productive systems, larger intracellular concentrations of $\mathrm{NO}_{3}^{-}, 7.1 \pm 6.7$ and

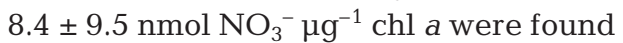
by Dortch et al. (1984) in Dabob Bay and by Pettersson (1991) in the Skagerrak, respectively.

Chlorophyll concentrations in our experiments were within the typical range of intertidal sediments (MacIntyre et al. 1996). The microphytobenthic community was likely dominated by diatoms, as suggested by the strong correlation between the chl $a$ and $c$ contents. Diatoms are usually the dominant microphytobenthic taxa in marine intertidal sediments (MacIntyre et al. 1996). Diatom cells contain large vacuoles in which $\mathrm{NO}_{3}{ }^{-}$can be stored fore, freezing of sediment samples for preservation is unacceptable if the variable of interest is the concentration of inorganic nutrient in the pore water.

Lomstein et al. (1990) found a 5-fold increase in the FL content for $\mathrm{NH}_{4}{ }^{+}$ and 18-fold for $\mathrm{NO}_{3}{ }^{-}$in the sediment after the sedimentation of the spring phytoplankton bloom. They suggested that freezing could release intracellular $\mathrm{NH}_{4}^{+}$and $\mathrm{NO}_{3}{ }^{-}$from the sedimented diatom cells. The strong statistical correlations between the concentration of FL-IN and the chl $a$ and $c$ content in the sediment of our area suggest that a large fraction of the FL-IN is closely associated with the microphytobenthic biomass (Table 1, Fig. 2). These results indicate that benthic microalgae store inorganic nutrients, as has been reported for planktonic diatoms (Dortch 1982, Thoresen et al. 1982, Dortch et al. 1984, Bode et al. 1997). Unfortunately, no information is available in the literature on the intracellular content of

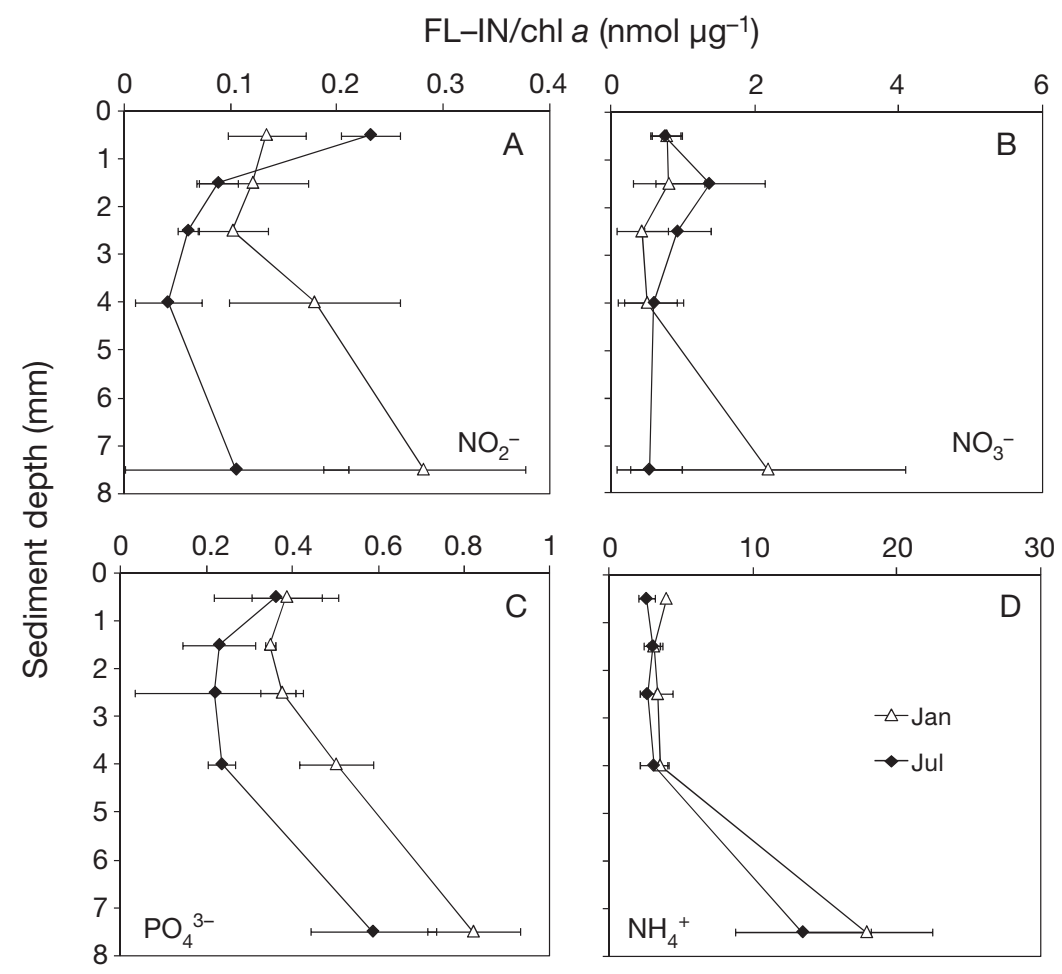

Fig. 5. Ratio of FL-IN per unit of chl a: (A) FL-NO ${ }_{2}^{-} / \mathrm{chl} a_{1}$ (B) FL-NO $\mathrm{NO}_{3}^{-} / \mathrm{chl} a_{\text {, }}$ (C) $\mathrm{FL}-\mathrm{PO}_{4}{ }^{3-} / \mathrm{chl} a$ and (D) FL- $\mathrm{NH}_{4}{ }^{+} / \mathrm{chl} a$. Nutrient and chl $a$ are expressed per gram of fresh weight, being the resulting ratio in nmol FL-IN/ $\mathrm{gg} \mathrm{chl} a$. Values are mean $\pm \operatorname{SE}(\mathrm{n}=3)$ 


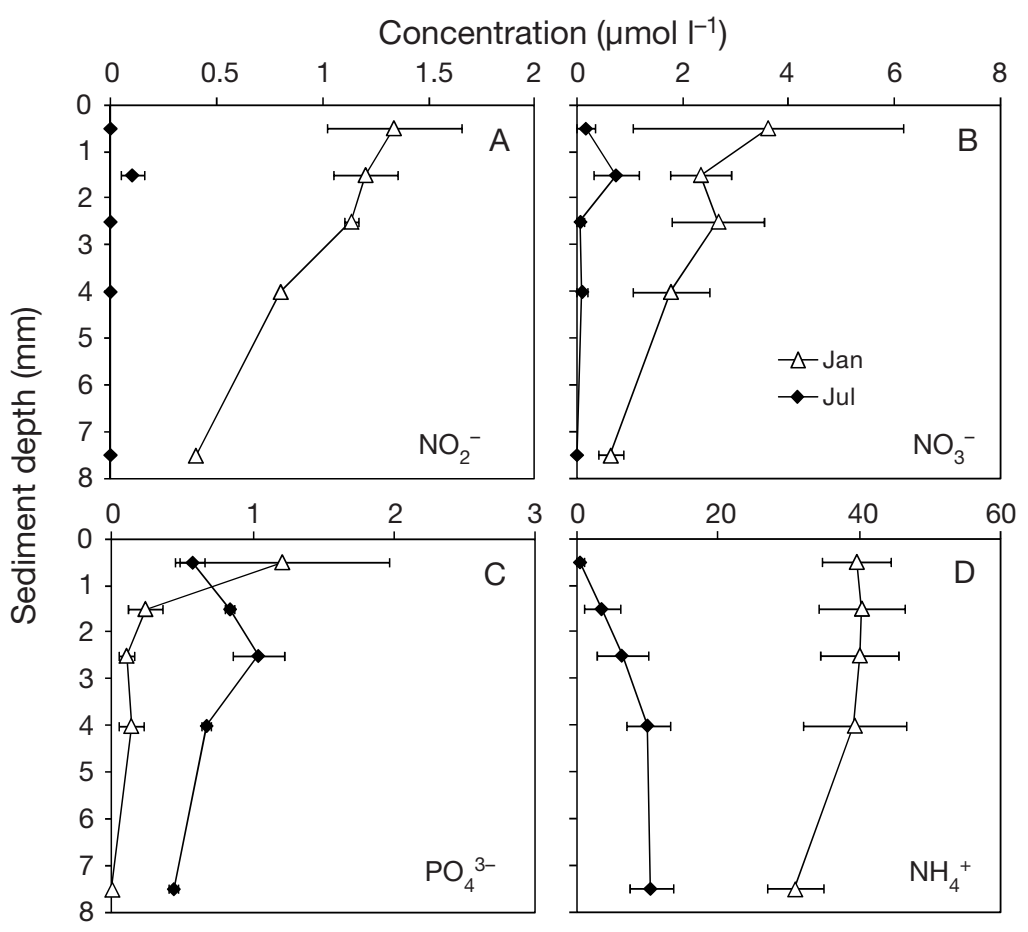

Fig. 6. Vertical profiles of (A) nitrite, (B) nitrate, (C) phosphate and (D) ammonium concentrations in the pore water in January and July. Values are mean $\pm \mathrm{SE}(\mathrm{n}=3)$

FL- $\mathrm{NO}_{3}{ }^{-} / \mathrm{chl}$ a ratio is likely to be more variable than $\mathrm{FL}-\mathrm{NH}_{4}{ }^{+} / \mathrm{chl} a$ in the sediment photic layer (Fig. 5).

In addition to microphotoautotrophs, other components of the microbenthic community might also contribute to the release of FL-IN. The KCl-lysable fraction of $\mathrm{NH}_{4}{ }^{+}$, defined as the $\mathrm{NH}_{4}{ }^{+}$extracted with $\mathrm{KCl}$ after freezing, has been shown to be around 80 times larger than $\mathrm{KCl}$ exchangeable $\mathrm{NH}_{4}{ }^{+}$, being also positively related to bacterial abundance (Aller 1994). High concentrations of $\mathrm{FL}_{-} \mathrm{NO}_{3}{ }^{-}$ were found in hypertrophic sediments colonised by the sulphur-oxidising bacteria Beggiatoa sp., which are capable of accumulating large amounts of $\mathrm{NO}_{3}{ }^{-}$(up to $100 \mathrm{mmol} \mathrm{l}^{-1}$ ) in their vacuoles (McHatton et al. 1996, Sayama 2001). Bacteria are able to store large amounts of $\mathrm{PO}_{4}{ }^{3-}$ as polyphosphate, and bacteria-associated $\mathrm{PO}_{4}{ }^{3-}$ represented a large fraction (up to $80 \%$ ) of total P in lake sediments (Gachter et al. 1988). Large vacuolated sulphuroxidising bacteria are absent in the typical intertidal sediments of Cádiz Bay, due to the relatively low organic matter con-

(Dortch et al. 1984, Stolte \& Riegman 1995, Lomas \& Glibert 2000). $\mathrm{PO}_{4}{ }^{3-}$ can be stored intracellularly as orthophosphate, most likely in the vacuole, or as polyphosphate in the cytoplasm (Miyata et al. 1986, Mateo et al. 2006). In addition, the existence of a phosphate pool adsorbed to the cell surface has been shown in marine phytoplankton (Fu et al. 2005). On the other hand, diatoms do not usually store large amounts of $\mathrm{NH}_{4}{ }^{+}$and $\mathrm{NO}_{2}{ }^{-}$intracellularly, most probably due to their toxicity (Dortch 1982, Lomas \& Glibert 2000). The differences in the capacity of benthic microalgae to use different species of inorganic nitrogen and phosphate for intracellular storage likely explain the differences observed in the relationships between the FL-IN and MPB biomass, both on an annual scale and when the relationships were analysed separately in summer and winter (Tables 1 \& 3). The highest statistical correlations between FL-IN and chl a were observed for FL$\mathrm{NH}_{4}{ }^{+}$and the lowest for $\mathrm{FL}-\mathrm{NO}_{3}{ }^{-}$. The high statistical correlation between FL- $\mathrm{NH}_{4}{ }^{+}$and chl $a$ is unexpected since pelagic diatoms are unable to store $\mathrm{NH}_{4}{ }^{+}$intracellularly. However, they can store large amounts of inorganic $\mathrm{N}$ in the form of $\mathrm{NO}_{3}{ }^{-}$(Dortch 1982, Lomas \& Glibert 2000). If the intracellular $\mathrm{NO}_{3}{ }^{-}$pool in benthic diatoms can be used as a dynamic cell reservoir, the relationship between $\mathrm{FL}-\mathrm{NO}_{3}{ }^{-}$and $\mathrm{chl} a$ is likely to be complex and variable, depending on MPB growth rate and $\mathrm{N}$-availability in the environment. Therefore, the tent and the absence of free sulphide in the sediment (García-Robledo et al. 2008, Corzo et al. 2009). Therefore, a large contribution of bacteria to the $\mathrm{FL}_{-}-\mathrm{NO}_{3}{ }^{-}$ pool is unlikely. However, a possible contribution of bacteria and micro- and meiofauna to the $\mathrm{FL}-\mathrm{PO}_{4}{ }^{3-}$ and, particularly, $\mathrm{FL}-\mathrm{NH}_{4}{ }^{+}$pools cannot be ruled out due to the general covariance of microphytobenthos abundance and primary production with bacterial and micro- and meiofaunal abundance (Middelburg et al. 2000). In addition, different types of phytodetritus might also contribute to the FL-IN pool of sediment (Lomstein et al. 1990, Corzo et al. 2009).

A proportion of the FL-IN could have an abiotic source as well. The freeze-thaw treatment could, to some extent, extract inorganic nutrients adsorbed to the sediment matrix, such as $\mathrm{NH}_{4}{ }^{+}$and $\mathrm{PO}_{4}{ }^{3-}$, usually referred to as the exchangeable pool (Blackburn \& Henriksen 1983, Slomp et al. 1998). The non-specific binding of $\mathrm{NO}_{3}{ }^{-}$to the sediment matrix is considered unlikely in marine sediment (Lomstein et al. 1990), although it does occur in soils (Katou et al. 1996). Our results indicate that changes in the concentration of chl a explained 94, 88, 72 and $54 \%$ of variability of FL$\mathrm{NH}_{4}{ }^{+}$, FL-PO ${ }_{4}{ }^{3-}, \mathrm{FL}_{-} \mathrm{NO}_{2}{ }^{-}$and $\mathrm{FL}-\mathrm{NO}_{3}{ }^{-}$, respectively, suggesting a strong relationship with MPB biomass. Nonetheless, the relative importance of the intracellular and exchangeable pools might change depending on the taxonomic composition of microbenthic commu- 
nity and, therefore, it could change with depth within the sediment. The significant increase of $\mathrm{FL}_{-} \mathrm{NH}_{4}{ }^{+} /$ $\mathrm{chl} a$ and $\mathrm{FL}-\mathrm{PO}_{4}{ }^{3-} / \mathrm{chl} a$ with depth below the photosynthetic layer suggests the existence of a FL-IN pool not associated with chl $a$, the relative importance of which increases with depth, as MPB biomass decreases (Fig. 5). Lomstein et al. (1990) observed that the proportions of the $\mathrm{KCl}$-extractable and FL pools changed with depth within the sediment. The KClextractable $\mathrm{NH}_{4}{ }^{+}$and $\mathrm{NO}_{3}{ }^{-}$were 50 and $25 \%$ of the $\mathrm{FL}$ concentrations, respectively, in the upper $\mathrm{mm}$ of the sediment, while they were similar or slightly higher below $5 \mathrm{~mm}$ depth (Lomstein et al. 1990).

\section{Seasonal differences}

Comparison of winter and summer samples revealed large differences in the FL and pore water pools of inorganic nutrients. The general absence of statistical correlations between the pore water nutrient concentration in the sediment and FL-IN and chl $a$ indicate that the FL-IN and the pore water pools are largely unrelated or at least not connected in a simple way. The only exception was $\mathrm{NO}_{3}{ }^{-}$in July, which correlated significantly with $\mathrm{FL}_{-} \mathrm{NO}_{3}{ }^{-}(\mathrm{p}<0.01)$. Interestingly, however, the slope of the regression equation changed from 4.42 in January to 23.60 in July, suggesting a larger accumulation of intracellular $\mathrm{NO}_{3}{ }^{-}$for a very low external nitrate concentration in the pore water (results not shown). The content of $\mathrm{FL}_{-} \mathrm{NO}_{3}{ }^{-}$normalised by $\mathrm{chl} a$ ( $\mathrm{FL}^{-\mathrm{NO}_{3}}{ }^{-} / \mathrm{chl} \mathrm{a}$ ) in the upper sediment layer also indicates a slightly higher content of intracellular nitrate in the microphytobenthic biomass in July than in January, although the differences were not significant due to high variability in the data (Fig. 5).

Microphytobenthic biomass, as estimated by chl $a_{\text {, }}$ was higher in winter (Table 2); however, the microphytobenthic community was more productive in summer, resulting therefore in a higher production/biomass ratio $(P / B)$. This higher $P / B$ ratio indicates a more rapid turnover and, therefore, a higher gross growth rate of MPB during this season. The high productivity and growth rate of MPB in summer also coincided with lower concentrations of $\mathrm{NO}_{3}^{-}, \mathrm{NH}_{4}^{-}$and $\mathrm{NO}_{2}^{-}$in the pore water compared to winter. The assimilation of $\mathrm{NO}_{3}{ }^{-}$and $\mathrm{NH}_{4}{ }^{+}$by MPB has been shown to play an essential role in the availability of these compounds at the sediment surface and their net fluxes to the water column (Sundbäck \& Miles 2002). Therefore, the lower concentration of inorganic nitrogen compounds in the pore water in summer could be attributed to their consumption by MPB.

The FL-IN pool was always higher in winter except in the case of $\mathrm{FL}-\mathrm{NO}_{3}{ }^{-}$. Therefore, a larger fraction of the sediment inorganic nutrients was immobilised in the microphytobenthic biomass in winter when MPB biomass, as estimated by chl a, was higher as well. However, the relative amount of FL-IN per unit of chl a in the sediment photic layer did not show significant changes with the season (Fig. 5). This is an unexpected result since, according to the cell quota model (Droop 1968), the intracellular content of nutrients in summer should be higher since $P_{\mathrm{n}}$ was significantly higher in this season. In addition, the storage of inorganic nutrients would provide MPB competitive advantage over bacteria, affecting the cycling of nutrients in the sediment.

\section{CONCLUSIONS}

The statistical relationship between the concentration of FL inorganic nutrients and chl a content in the sediment indicates that the main source of these nutrients is most likely the intracellular pool of MPB. Freezing and thawing of sediment samples breaks MPB cells, releasing their intracellular content into the pore water and increasing the efficiency of chlorophyll extraction. Nonetheless, other components of the sediment biological community like bacteria and meiofauna might be responsible for a fraction of the released nutrient. In addition, part of the $\mathrm{FL}^{-} \mathrm{NH}_{4}{ }^{+}$and FL- $\mathrm{PO}_{4}{ }^{3-}$ might have been released from the exchangeable pool, adsorbed to the sediment matrix. The relative importance of the different biotic and abiotic sources of FL-IN is likely to change with the taxonomic composition of the benthic community and with the characteristics of the sediment. Therefore, if the aim is to measure nutrient concentrations in the pore water, the extraction should be done from fresh samples.

The independence and higher concentration of the FL-IN pool with respect to pore water concentration also indicated that MPB can actively accumulate nutrients. These intracellular nutrients are a variable and dynamic pool which could influence both microphytobenthic primary production and the sediment-water fluxes. In addition, the relationships between biomass (estimated here by chl a), FL-IN and pore water nutrients seem to be very dynamic, changing with depth within sediment and between summer and winter seasons.

Acknowledgements. The research was funded by grants CTM2006-04015 and CTM2009-10736 (Ministry of Education and Science, Spain) and P06-RNM-01787 (Junta de Andalucía) to A.C., and a FPU grant (AP2005-4897) from the Ministry of Education and Science to E.G. and a JAE-DOC fellowship to S.P. The authors thank 4 anonymous reviewers whose suggestions helped to improve the manuscript. 


\section{LITERATURE CITED}

Aller RC (1994) Bioturbation and remineralization of sedimentary organic matter: effects of redox oscillation. Chem Geol 114:331-345

Berg P, Risgaard-Petersen N, Rysgaard S (1998) Interpretation of measured concentration profiles in sediment pore water. Limnol Oceanogr 43:1500-1510

Blackburn TH, Henriksen K (1983) Nitrogen cycling in different types of sediments from Danish waters. Limnol Oceanogr 28:477-493

Bode A, Botas JA, Fernández E (1997) Nitrate storage by phytoplankton in a coastal upwelling environment. Mar Biol 129:399-406

Boudreau BP (1997) Diagenetic models and their interpretation: modelling transport and reactions in aquatic sediments. Springer, Berlin

Corzo A, Van Bergeijk SA, García-Robledo E (2009) Effects of green macroalgal blooms on intertidal sediments: net metabolism and carbon and nitrogen contents. Mar Ecol Prog Ser 380:81-93

Dortch Q (1982) Effect of growth conditions on accumulation of internal nitrate, ammonium, amino acids, and protein in three marine diatoms. J Exp Mar Biol Ecol 61:243-264

Dortch Q, Clayton JR, Thoresen SS, Ahmed SI (1984) Species differences in accumulation of nitrogen pools in phytoplankton. Mar Biol 81:237-250

Droop MR (1968) Vitamin B12 and marine ecology, IV. J Mar Biol Assoc UK 48:689-733

Ferguson AJP, Eyre BD, Gay JM (2004) Benthic nutrient fluxes in euphotic sediments along shallow sub-tropical estuaries, northern New South Wales, Australia. Aquat Microb Ecol 37:219-235

Fu F, Zhang Y, Leblanc K, Saudo-Wilhelmy S, Hutchins D (2005) The biological and biogeochemical consequences of phosphate scavenging onto phytoplankton cell surfaces. Limnol Oceanogr 50:1459-1472

Gachter R, Meyer J, Mares A (1988) Contribution of bacteria to release and fixation of phosphorus in lake sediments. Limnol Oceanogr 33:1542-1558

> García-Robledo E, Corzo A, García de Lomas J, van Bergeijk SA (2008) Biogeochemical effects of macroalgal decomposition on intertidal microbenthos: a mesocosm experiment. Mar Ecol Prog Ser 356:139-151

Grasshoff K, Ehrhardt M, Kremling K (1983) Methods of sea water analysis, Vol 1. Verlag Chemie, New York, NY

Katou H, Clothier BE, Green SR (1996) Anion transport involving competitive adsorption during transient water flow in an andisol. Soil Sci Soc Am J 60:1368-1375

Kühl M, Glud RN, Ploug H, Ramsing N (1996) Microenviromental control of photosynthesis and photosynthesiscoupled respiration in an epilithic cyanobacterial biofilm. J Phycol 32:799-812

Lomas MW, Glibert PM (2000) Comparison of nitrate uptake, storage and reduction in marine diatoms and flagelates. J Phycol 36:903-913

Lomstein E, Jensen MH, Sørensen J (1990) Intracellular $\mathrm{NH}_{4}{ }^{+}$ and $\mathrm{NO}_{3}{ }^{-}$pools associated with deposited phytoplankton in a marine sediment (Aarhus Bight, Denmark). Mar Ecol Prog Ser 61:97-105

MacIntyre HL, Geider RJ, Miller DC (1996) Microphytoben-

Editorial responsibility: Matthias Seaman,

Oldendorf/Luhe, Germany thos: The ecological role of the 'secret garden' of unvegetated, shallow-water marine habitats. I. distribution, abundance and primary production. Estuaries 19:186-201

> Mateo P, Douterelo I, Berrendero E, Perona E (2006) Physiological differences between two species of cyanobacteria in relation to phosphorous limitation. J Phycol 42:61-66

> McHatton SC, Barry JP, Jannasch HW, Nelson DC (1996) High nitrate concentrations in vacuolate, autotrophic marine Beggiatoa spp. Appl Environ Microbiol 62: 954-958

Middelburg JJ, Barranguet C, Boschker HTS, Herman PMJ, Moens T, Heip CHP (2000) The fate of intertidal microphytobenthos carbon: an in situ 13C-labeling study. Limnol Oceanogr 45:1224-1234

Miyata K, Hattori A, Ohtsuki A (1986) Variation of cellular phosphorus composition of Skeletonema costatum and Heterosigma akashiwo grown in chemostats. Mar Biol 93: 291-297

More MI, Herrick JB, Silva MC, Ghiorse WC, Madsen EL (1994) Quantitative cell lysis of indigenous microorganisms and rapid extraction of microbial DNA from sediment. Appl Environ Microbiol 60:1572-1580

> Otero M, Mendonça A, Válega M, Santos EBH, Pereira E, Esteves VI, Duarte A (2007) Fluorescence and DOC contents of estuarine pore waters from colonized and noncolonized sediments: effects of sampling preservation. Chemosphere 67:211-220

Pettersson K (1991) Seasonal uptake of carbon and nitrogen and intracellular storage of nitrate in planktonic organisms in the Skagerrak. J Exp Mar Biol Ecol 151:121-137

Ritchie RJ (2008) Universal chlorophyll equations for estimating chlorophylls $a, b, c$, and $d$ and total chlorophylls in natural assemblages of photosynthetic organisms using acetone, methanol, or ethanol solvents. Photosynthetica 46:115-126

Sayama M (2001) Presence of nitrate-accumulating sulfur bacteria and their influence on nitrogen cycling in a shallow coastal marine sediment. Appl Environ Microbiol 67: 3481-3487

Slomp CP, Malschaert JFP, Van Raaphorst W (1998) The role of adsorption in sediment-water exchange of phosphate in North Sea continental margin sediments. Limnol Oceanogr 43:832-846

Stolte W, Riegman R (1995) Effect of phytoplankton cell size on transient-state nitrate and ammonium uptake kinetics. Microbiology 141:1221-1229

Sundbäck K, Miles A (2002) Role of microphytobenthos and denitrification for nutrient turnover in embayments with floating macroalgal mats: a spring situation. Aquat Microb Ecol 30:91-101

Thompson RC, Tobin ML, Hawkins SJ, Norton TA (1999) Problems in extraction and spectrophotometric determination of chlorophyll from epilithic microbial biofilms: towards a standard method. J Mar Biol Assoc UK 79: $551-558$

> Thoresen SS, Dortch Q, Ahmed SI (1982) Comparison of methods for extracting intracellular pools of inorganic nitrogen from marine phytoplankton. J Plankton Res 4: 695-704

Wasmund N, Topp I, Schories D (2006) Optimising the storage and extraction of chlorophyll samples. Oceanologia 48: $125-144$

Submitted: July 15, 2009; Accepted: December 21, 2009 Proofs received from author(s): March 2, 2010 